\title{
THE PSYCHOLOGICAL CONTRACT FOR HEALTHCARE WORKERS
}

\begin{abstract}
BLANCA GRAMA ${ }^{1}$
1 “Lucian Blaga” University of Sibiu

Keywords: psychological contract, work engagement, burnout, organizational support

Abstract: Healthcare workers are more vulnerable to burnout due to the fact that they often face stressful situations that involve high levels of risk and emotional involvement, especially if they are exacerbated by patients they provide care to. The activity in the medical field is not only physically demanding, but also socio-emotional, being necessary a better understanding of the socio-emotional aspects present in the employment relationship. The health sector is facing continuous changes and reforms, periods of uncertainty when the fulfilment of the psychological contract is less probable. We propose the description of a relational model between the psychological contract with work engagement, burnout, organizational support and the intention to leave the organization for the medical staff. The results show that organizational support influences work-related outcomes and emphasizes the importance of examining organizational contexts, such as contract status, to understand the influence of support on work involvement and burnout.
\end{abstract}

\section{INTRODUCTION}

Healthcare employees spend many hours a day at work, which becomes the place where they engage in goaloriented activities, aim to find meaning and make efforts for development. If an employee feels passionate about his job, he becomes part of the organization, will put extra effort into his job, and will collaborate better with other members of the organization. An employee actively involved and highly engaged in the work will take on more difficult tasks, will be more motivated to promote, and will actively promote the interests of the company. Lack of commitment to the organization leads to the intention to leave the organization. This means that when a person is actively engaged in his work, he will be more passionate about his job, will be more actively engaged with the organization and then will put extra effort into the job he has.

The psychological contract provides the opportunity to explore the processes and content of the employment relationship by focusing on more or less explicit agreements. These understandings can be renegotiated or changed over time, being influenced by a number of contextual factors and generating a variety of consequences (1). Guest in 2004, (2), mentions that the main focus of the psychological contract is the specificity and type of employment relationship between employer and employee. Research shows that employees who perceive high levels of perceived organizational support will respond through positive behaviours in the workplace, will have increased performance, organizational efficiency, and will show attachment to the organization. $(3,4)$

According to the theory of the psychological contract, the employee develops a set of obligations established during the initial phases of the employment relationship (5), contractual obligations that guide his behaviour, and in turn the organization rewards him in relation to the performance it will capitalize.(6)
Healthcare workers are more vulnerable to burnout due to the fact that they often face stressful situations that involve high levels of risk and emotional involvement, especially if they are exacerbated by patients they provide care to. At the same time, the activity in the medical field is not only physically demanding, but also socio-emotional, being necessary a better understanding of the socio-emotional aspects present in the employment relationship (for example, psychological contract fulfilment). At the same time, the health sector is facing continuous changes and reforms, periods of uncertainty when the fulfilment of the psychological contract is less probable.

\section{AIM}

In such situations, understanding the interaction between the characteristics of the job, the psychological contract and the results of the work for healthcare workers is appropriate.

We propose the description of a relational model between the psychological contract with work engagement, burnout, organizational support and the intention to leave the organization for the medical staff from the studied sample.

\section{MATERIALS AND METHODS}

\section{Instruments}

The Psychological Contract Measure (7) translated and adapted for Romania by Grama Blanca, was used to evaluate the state of the psychological contract.

To assess the perceived organizational support, it was used the Organizational Support Questionnaire, created by Eisenberger Huntington, Hutchison and Sowa in 1986 and adapted on the Romanian population by Chirazof in 2014 (8).

Work engagement was measured with the Utrecht Scale, the 9-item variant (Utrecht Work Engagement Scale, UWES), was built by Schaufeli and Bakker in 2003 and adapted

${ }^{1}$ Corresponding author: Blanca Grama, Str. Pădurea Dumbrava, Nr. 14, Sibiu, România, Email: blanca.grama@ulbsibiu.ro, Phone: +40733552960 Article received on 10.10.2020 and accepted for publication on 15.12.2020 
to the Romanian population by Vîrgă, Sulea, Zaborilă and Maricutoiu in 2009.(9) The authors describe the Utrecht Scale as being composed of three constitutive dimensions of work involvement: vigour, dedication and absorption.

The intention to leave the organization was measured with items that belong to the scale developed by Price in 2001, items that were included in the study Psycones.(10)

The Oldenburg Burnout Inventory was measured with the Oldenburg Burnout Inventory (OLBI) Demerouti and Bakker, in 2008. Exhaustion is the result of prolonged exposure to certain demands at work and includes feelings such as emotional emptiness, overwork, a strong need for rest and physical exhaustion. Disengagement is the distancing of the employee from his own work and the support of negative or cynical attitudes related to his own work in general.

\section{Sample selection}

The participants in this study were employees in the medical sector, the convenience sample consisting of 241 respondents, Romanian healthcare employees, of whom 197 women and 44 men $(81.8 \%$ women and $18.2 \%$ men) aged between 20 and 60 years (distribution that reflects an increased share of women among employees in the medical sector). The anonymity and confidentiality of the respondents' data were guaranteed, according to the deontological norms specific to the Romanian legislation.

\section{RESULTS}

To verify and configure a relational model of variables we used the statistical processing program $\mathrm{R}$, and as specifications for estimation: we used EBICglasso which uses maximum probability estimation, the result being a network in which connections between nodes represent a partial zero correlation, controlling in all the other nodes in the network at the same time.

\section{Figure no. 1. The network of the analysed variables}

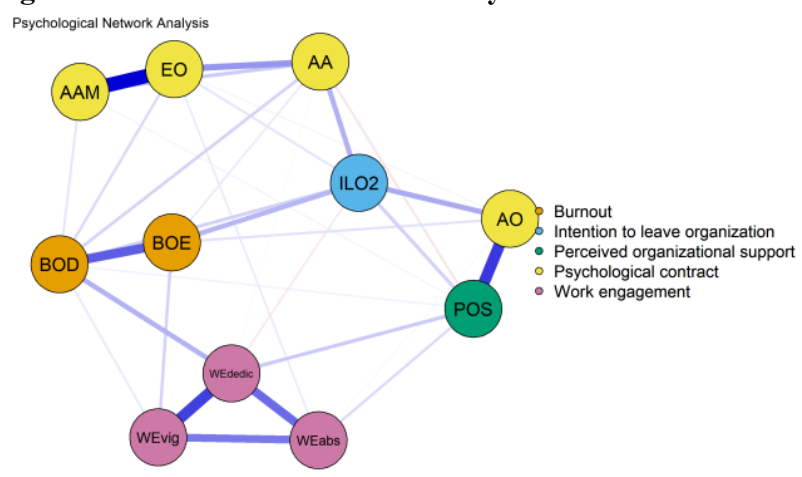

AA - expect employee; POS - perceived organizational support; WE - Wevigor; WE - Wededication;ILO - Intention to leave organization; $\mathrm{EO}$ - offer employee; BOD - disengagement; BOE - exhaustion; AAM - expect employer.

The structure of the network, estimated from the LASSO graphical algorithm in combination with the selection of the EBIC model, showed that the nodes belonging to the same construct were associated and close to each other and well separated those belonging to different constructs.

The visual inspection of the network in Figure 1 reveals a division into four different communities: (1) work involvement with its three dimensions of vigor, dedication and absorption - a well-defined concentration of dimensions describing work involvement; (2) the two dimensions of burnout, disengagement and exhaustion - which describe a welldefined distribution of the dimensions that describe burnout; (3) three dimensions of the psychological contract, which describe the expectations of the employee and the employer; and (4) the group of variables that describe the organizational support and the obligations of the employer that are associated. The analysis of the figure indicates the variable intention to leave the organization, as having a certain centrality, which acts as a bridge that connects the communities to formed nodes.

\section{DISCUSSIONS}

The analysis of the study results and the visual inspection of the network show us a non-unitary construct of the psychological contract; on the one hand we have the variable AA (... I expect from my employer), EO (.... the employer expects from me) and AAM (... I offer to my employer) and on the other hand we have AO ( ... my employer offers me). We must not neglect in interpretation the meaning of the concept.

The term expectations, used in the psychological contract questionnaire, expresses that something is considered reasonable, or is due to the employment partnership based on the experiences of the employment relationship and, therefore, captures the idea of an implicit contract. In order to differentiate between expectations and offers, participants had to focus on the specific employment relationship and not take into account the expectations they had before hiring in that position. The offer term rather expresses the support of a concerted situation, an aspect that was much more palpable perceived by the respondents. Employees perceive the employer's offer in the form of loyalty, support, job security, career development opportunities, decision-making involvement.

We appreciate that the dimensions AA (... I expect from my employer), $\mathrm{BC}$ (.... the employer expects from me) and $\mathrm{BE}$ (... I offer to my employer) measure the employee's perception, and AO (... my employer offers) rather measures an aspect of reality, the employees not identifying the psychological contract as a unitary construct. This nonuniformity of the appreciation of the construct also has an impact on the results of the present study.

The visual inspection of the network reveals a variable in the network, the intention to leave organization, ILO, which has high centrality, with a node strength of 0.85 . This variable has significant links with two of the dimensions of the psychological contract, namely AA (... I expect from my employer) and $\mathrm{AO}$ (... my employer offers me), dimensions that reflect only the relationship with the employer

The result is in agreement with Turnley and Feldman in 2000 (11), as well as Flood, Turner, Ramamoorthy and Pearson in 2001 (12) who showed that the intention to resign is positively affected by the fulfilment of employers' obligations or promises. The results obtained by us are consistent with other findings of Dutch research.(13) If employees intend to quit but are forced to remain in the organization for multiple reasons, they will develop manifestations of frustration and exhaustion.(11) When work demands and resources are low, it leads to exhaustion, which is the opposite of involvement, which in turn stimulates the intention to leave the organization.

When employees from medical healthcare perceive that the organization is fulfilling its psychological contract, their attitudes are reflected in greater involvement in work and lower intention to leave the organization. According to the theory of social exchange, when employees assume their promises as fulfilled by the employer, they act accordingly by offering each other fulfilment in the form of positive work attitudes and behaviours. Therefore, a psychological contract fulfilment leads to a higher degree of involvement and a lower intention to leave the organization.(14)

\section{CONCLUSIONS}

The results of this study show that organizational support influences work-related outcomes and emphasizes the importance of examining organizational contexts, such as 


\section{PUBLIC HEALTH AND MANAGEMENT}

contract status, to understand the influence of support on work involvement and burnout. The effects of the interaction between job characteristics and resources on the performance of psychological contracts, recommends that in order to enhance positive attitudes in the workplace, organizations should explore ways to provide employees with additional services and complex resources.

The study has important implications for medical management. In the hospital context, as medical activity is characterized by both high physical and psychological demands (patient interaction), hospitals should consider providing a wider range of resources, including workplace-oriented interventions (e.g., autonomy workplace) that provides employees with flexibility on how to meet various job requirements.(15,16) The psychological contract fulfilment is activated continuously, through a cognitive process of reconciling the characteristics of work with the perceptions about the promises and obligations in the employment relationship. Thus, organizations should take steps to continuously reconfigure the characteristics of the position to help maintain the fulfilment of the psychological contract as the roles of employees change and evolve with the dynamics of the internal and external organizational environment.

Following the results obtained, except for certain limits that can be controlled in the future, we can appreciate that this study makes contributions to highlight the contribution of the organization to employee development.

\section{REFERENCES}

1. De Cuyper N, De Witte H. The impact of job insecurity and contract type on attitudes, well-being and behavioural reports: A psychological contract perspective. Journal of Occupational and Organizational Psychology. 2006;79:395-409.

2. Guest DE. The Psychology of the Employment Relationship: An Analysis Based on the Psychological Contract. Applied psychology: an international review. 2004;53(4):541-555.

3. Guest DE, Conway, N. Communicating the psychological contract: an employer perspective. Human Resource Management Journal. 2002;12:22-38

4. Cropanzano R, Mitchell M. Social exchange theory. An interdisciplinary review. Journal of Management. 2005;31(6):874-900.

5. Rousseau DM. Why workers still identify with organizations. Journal of Organizational Behavior. 1998;19:217-233.

6. Rousseau DM, Hansen SD, Tomprou M. A dynamic phase model of psychological contract processes. Journal of Organizational Behavior. 2018;1(18).

7. Raeder S, Wittekind A, Inauen A, Grote G. Testing a psychological contract measure in a Swiss employment context. Swiss Journal of Psychology. 2009;68(4):177-188.

8. Chirazof CF. Efectul mediator al sprijinului organizațional perceput asupra relației dintre compatibilitatea percepută între persoană și organizație și sentimentul de împuternicire la locul de muncă. Psihologia Resurselor Umane. 2014;12(2):114-129.

9. Vîrgă D, Sulea C, Zaborilă C, Maricuțoiu L. Adaptarea în limba română a Scalei Utrecht de măsurare a implicării în muncă: examinarea validităţii şi fidelității. Psihologia Resurselor Umane. 2009;7(1):58-75.

10. Boroș S, Curșeu PL. Contracte psihologice în relaţiile de muncă. Date privind calitățile psihometrice ale chestionarului Psychones pe un eșantion românesc. Psihologie Organizaţională. 2008;5(2-3):123-145

11. Turnley WH, Feldman DC. Re-examining the effects of psychological contract violations: unmet expectations and job dissatisfaction as mediators. Journal of Organizational Behavior. 2000;21:25-42.

12. Flood PC, Turner T, Ramamoorthy N, Pearson J. Causes and consequences of psychological contracts among knowledge workers in the high technology and financial services industries. International Journal of Human Resource Management. 2001;12(7):1152-1165.

13. Schalk R, Freese C. How to measure the psychological contract? A critical criteria-based review of measures. South African Journal of Psychology. 2008;38(2):269-286.

14. Turnley W, Bolino M, Lester S, Bloodgood J. The impact of psychological contract fulfillment on the performance of in-role and organizational citizenship behavior. Journal of Management. 2003;29(2):187-206.

15. Chowdhury SK, Endres ML. The impact of client variability on nurses' occupational strain and injury: Crosslevel moderation by safety climate. Academy of Management Journal. 2010;53:182-198.

16. Popa F, Arafat R, Purcărea VL, Lală A, Popa-Velea O, Bobirnac G, Davilla C. Occupational burnout levels in emergency medicine - A nationwide study and analysis. Journal of Medicine and Life. 2010;3:449-453 